\title{
Effects of NMDA receptor antagonists and antipsychotics on high frequency oscillations recorded in the nucleus accumbens of freely moving mice
}

\author{
Mark J. Hunt ${ }^{1,2}$ - Maciej Olszewski ${ }^{1}$ - Joanna Piasecka ${ }^{1}$ - Miles A. Whittington ${ }^{2}$. \\ Stefan Kasicki ${ }^{1}$
}

Received: 4 April 2015 / Accepted: 9 September 2015 / Published online: 8 October 2015

(C) The Author(s) 2015. This article is published with open access at Springerlink.com

\begin{abstract}
Rationale Abnormal oscillatory activity associated with $\mathrm{N}$ methyl-D-aspartate (NMDA) receptor hypofunction is widely considered to contribute to the symptoms of schizophrenia. Objective This study aims to characterise the changes produced by NMDA receptor antagonists and antipsychotics on accumbal high-frequency oscillations (HFO; $130-180 \mathrm{~Hz}$ ) in mice.

Methods Local field potentials were recorded from the nucleus accumbens of freely moving mice.

Results Systemic injection of ketamine and MK801 both dose-dependently increased the power of HFO and produced small increases in HFO frequency. The atypical antipsychotic drug, clozapine, produced a robust dose-dependent reduction in the frequency of MK801-enhanced HFO, whilst haloperidol, a typical antipsychotic drug, had little effect. Stimulation of NMDA receptors (directly or through the glycine site) as well as activation of 5- $\mathrm{HT}_{1 \mathrm{~A}}$ receptors, reduced the frequency of MK801-enhanced HFO, but other receptors known to be targets for clozapine, namely $5-\mathrm{HT}_{2 \mathrm{~A}}, 5-\mathrm{HT}_{7}$ and histamine $\mathrm{H}_{3}$ receptors had no effect.

Conclusions NMDA receptor antagonists and antipsychotics produce broadly similar fundamental effects on HFO, as
\end{abstract}

Electronic supplementary material The online version of this article (doi:10.1007/s00213-015-4073-0) contains supplementary material, which is available to authorized users.

Mark J. Hunt

mhunt@nencki.gov.pl

1 Laboratory of the Limbic System, Nencki Institute of Experimental Biology, 3 Pasteur Street, 02-093 Warsaw, Poland

2 The Hull York Medical School, University of York, Heslington, York YO10 5DD, UK reported previously for rats, but we did observe several notable differences. In mice, HFO at baseline were weak or not detectable unlike rats. Post-injection of NMDA receptor antagonists HFO was also weaker but significantly faster. Additionally, we found that atypical antipsychotic drugs may reduce the frequency of HFO by interacting with NMDA and/ or $5-\mathrm{HT}_{1 \mathrm{~A}}$ receptors.

Keywords NMDA receptor antagonists · Antipsychotics · Oscillations $\cdot$ Mice $\cdot$ Schizophrenia

\section{Introduction}

$N$-methyl-D-aspartate (NMDA) receptor hypofunction has been proposed to contribute to the symptoms of schizophrenia. Acute administration of NMDA receptor antagonists produces transient psychosis-like activity in healthy humans and exacerbates the pre-existing symptoms in stabilised schizophrenic individuals (Krystal et al. 1994; Lahti et al. 1995). This suggests that NMDA receptor antagonists can interact with neuronal networks that mediate psychosis.

Oscillations recorded in local field potentials (LFP) or electroencephalograms (EEG) are generated by synchronous changes in the membrane potentials of a population of neurons which can be a few hundred thousand for LFP and several million for EEG recordings. Abnormal oscillatory activity recorded in EEG has been associated with schizophrenia (Uhlhaas and Singer 2010; Spencer 2011). An increasing number of studies have used these techniques in attempts to understand how NMDA receptor hypofunction influences regional brain activity. In experimental rodents, acute application of NMDA receptor antagonists is known to influence oscillations recorded in LFP (Ma and Leung 2000; 
Middleton et al. 2008; Roopun et al. 2008; Kocsis 2012) and electrocorticograms (Pinault 2008; Phillips et al. 2012).

The nucleus accumbens (NAc) is a brain region that has been implicated widely in the pathophysiology of schizophrenia (Grace 2000). Previously, we identified a high-frequency oscillation (HFO; $130-180 \mathrm{~Hz}$ ) recorded in the rat NAc that is enhanced substantially following systemic or local administration of NMDA receptor antagonists (Hunt et al. 2006). In the NAc, increases in the power of HFO produced by NMDA receptor antagonists predominate well above changes found in other frequency bands (Hunt et al. 2010). In recent years, a number of studies have demonstrated that a HFO band can be recorded in a variety of neuroanatomical and functionally distinct regions following injection of NMDA receptor antagonist (Hunt et al. 2011; Nicolas et al. 2011; Kulikova et al. 2012; Phillips et al. 2012; Ji et al. 2013; Hiyoshi et al. 2014). Tetrodotoxin infusion to the NAc produces profound reductions in HFO power which correlate with changes recorded in distant cortical sites, indicating the NAc may be an important generator of HFO (Olszewski et al. 2013a). In rats, atypical antipsychotic drugs (i.e. clozapine) reduce the frequency of accumbal HFO to a greater extent than typical drugs (i.e. haloperidol) (Olszewski et al. 2013b). Whilst both drug types bind to dopamine D2 receptors, atypical drugs differ from typical drugs in their mechanism of action. The improved efficacy of atypical antipsychotic compounds has been attributed to their additional powerful action at serotonergic receptors, perhaps most notably 5$\mathrm{HT}_{2 \mathrm{~A}}$, but also $5-\mathrm{HT}_{1 \mathrm{~A}}$ and $5-\mathrm{HT}_{7}$ receptors (Meltzer 1999). Compounds that bind to serotonergic receptor subtypes can block NMDA receptor antagonist-induced hyperlocomotion (Gleason and Shannon 1997) and attentional impairments (Higgins et al. 2003; Mirjana et al. 2004) and may reverse dysfunctional glutamatergic transmission produced by NMDA receptor antagonists (Ceglia et al. 2004; McOmish et al. 2012). Amongst the array of actions at other receptor systems, atypical antipsychotics are known to antagonise histamine $\mathrm{H}_{3}$ receptors (Rodrigues et al. 1995) and potentiate NMDA receptor currents (Wittmann et al. 2005). These actions may also contribute to the clinical profile of drugs such as clozapine. Experimental compounds that interact at these sites have been proposed as novel antipsychotics or adjunctive therapy in the treatment of schizophrenia (Wittmann et al. 2005; Ito 2009).

To date, the majority of animal model studies have focused on rats, mainly due to the convenience of the implantation in this species and for comparison with earlier studies. Effects of NMDA receptor antagonists on LFP oscillations recorded in mice, which are also a widely used experimental animal, are less well investigated. In freely moving mice, ketamine has been shown to decrease the power of basal hippocampal theta $(3-12 \mathrm{~Hz})$ and increase gamma $(30-80 \mathrm{~Hz})$ power (Lazarewicz et al. 2010); however, effects on HFO remain largely unknown. A recent study demonstrated that administration of ketamine generated significantly higher cortical power in the HFO band in Sp4 hypomorphic mice (decreased expression of NR1 protein) compared with wild-type siblings (Ji et al. 2013). However, in this study, a negligible increase in HFO power was observed in wild-type mice despite the relatively high dose of ketamine used $(50 \mathrm{mg} / \mathrm{kg})$. This may suggest a difference in the generation of HFO between species. Since, in rats, the NAc appears to be a locus for generation of HFO, this prompted us to investigate whether the same holds true for mice. This issue gains importance considering the increasing number of genetic mouse models and emergence of optogenetic techniques reliant on modified genetic background for neuronal specificity. In this study, we also used a pharmacological strategy to shed light on the mechanism through which atypical antipsychotics reduce the frequency of HFO.

\section{Methods}

\section{Surgery}

Thirty-four male C57BL/6 and 10 BALB/c mice (20-28 g) were implanted with a pair of twisted stainless steel electrodes (125 $\mu \mathrm{m}$, Science Products, Germany) in the NAc (AP, $1.3 \mathrm{~mm}$; ML, $0.75 \mathrm{~mm}$; DV, $4.2 \mathrm{~mm}$ ). In all cases, a silver wire was used as ground/reference electrode connected to a screw posterior to the bregma. Mice were housed individually with access to water and food ad libitum. The location of tips of electrode (electrolytic lesion) was determined on $40-\mu \mathrm{m}$ Cresyl violet-stained sections.

\section{Experimental groups}

Mice were placed in a recording chamber $(35 \times 35 \times 42 \mathrm{~cm})$. LFP were recorded through a JFET pre-amplifier. The signal was relayed through a commutator (Plastics One) amplified $\times 1000$, filtered $0.1-1 \mathrm{kHz}$ (A-M Systems, USA) and digitised $4 \mathrm{kHz}$ (Micro1401, CED, Cambridge, UK). Data were stored on a PC for offline analysis.

Mice were assigned to six experimental groups (see Supplementary Table 1). Group $1(n=4)$ includes $20 \mathrm{~min}$ baseline followed by injection of 10, 25 and $50 \mathrm{mg} / \mathrm{kg}$ ketamine or vehicle; group $2(n=5)$ includes $20 \mathrm{~min}$ baseline followed by injection of $0.05,0.1,0.25$ and $0.5 \mathrm{mg} / \mathrm{kg}$ MK801 or vehicle; group $3(n=6)$ includes $20 \mathrm{~min}$ baseline followed by injection of $0.25 \mathrm{mg} / \mathrm{kg} \mathrm{MK} 801$, followed $30 \mathrm{~min}$ later by injection of 1,5 and $15 \mathrm{mg} / \mathrm{kg}$ clozapine or vehicle; group $4(n=$ 7) includes $20 \mathrm{~min}$ baseline followed by $0.25 \mathrm{mg} / \mathrm{kg}$ MK801, followed $30 \mathrm{~min}$ later by $2.0 \mathrm{~g} / \mathrm{kg}$ glycine, $75 \mathrm{mg} / \mathrm{kg}$ NMDA or vehicle; and group $5(n=6)$ includes $20 \mathrm{~min}$ baseline followed by injection of $0.25 \mathrm{mg} / \mathrm{kg}$ 
MK801, followed $30 \mathrm{~min}$ later by $1.0 \mathrm{mg} / \mathrm{kg} 8-\mathrm{OH}-$ DPAT, $1.0 \mathrm{mg} / \mathrm{kg}$ MDL 11, 939 or vehicle. Some mice $(n=10)$ from groups 4 and 5 also received injection (intraperitoneal (i.p.)) of $1.5 \mathrm{mg} / \mathrm{kg}$ haloperidol $30 \mathrm{~min}$ post-MK801, and locomotor activity (LMA) was evaluated in four of these mice. Group $6(n=5)$ includes $20 \mathrm{~min}$ baseline followed by $0.25 \mathrm{mg} / \mathrm{kg}$ MK 801 , followed $30 \mathrm{~min}$ later by injection of a low dose of haloperidol $(0.15 \mathrm{mg} / \mathrm{kg})$ or vehicle and group $7(n=6)$ includes $20 \mathrm{~min}$ baseline followed $20 \mathrm{~min}$ later by injection of $0.25 \mathrm{mg} / \mathrm{kg} \mathrm{MK} 801$, followed $30 \mathrm{~min}$ later by injection of $1.0 \mathrm{mg} / \mathrm{kg} \mathrm{SB} 269970,5.0 \mathrm{mg} / \mathrm{kg}$ BF2649 or vehicle. With exception of group 2, locomotor activity was assessed by beam breaks (Columbus Instruments, USA). The experiments were performed according to Latin-square design, whereby each animal with the individual groups received all injection(s) assigned in a pseudorandomised order. All experiments were conducted in accordance with the European Community guidelines on the Care and Use of Laboratory Animals (86/ 609/EEC) and approved by a local ethics committee.

Selection of drugs and doses were based on published findings demonstrating reversal of the effects of NMDA receptor antagonists on motor, cognitive or neurotransmitter effects (Gleason and Shannon 1997; Ninan and Kulkarni 1998; Higgins et al. 2003; Mirjana et al. 2004; Ligneau et al. 2007; Horiguchi et al. 2011; Brabant et al. 2013; Nikiforuk et al. 2013).

\section{Data analysis}

LFP signals were inspected for movement artefacts which when present were removed. These were infrequent events which typically corresponded to large amplitude deflections of the raw LFP, usually associated with impact of the headset with the wall of the recording chamber. Mean power spectra of the raw LFP were carried out on successive 60-s data blocks using a fast Fourier transform of 4096 points (Spike 2). Total power $(130-180 \mathrm{~Hz})$ and dominant frequency were calculated. We also analysed 10-min means at the end of the 60min time course, unless stated otherwise.

\section{Statistics}

Data were analysed using analysis of variance (ANOVA) with time as the repeated measure followed by the Bonferroni post hoc test. Means of $10 \mathrm{~min}$ with or without drug were compared using one-way ANOVA followed by the Bonferroni post hoc test or Student's paired $t$ tests if only two groups were compared. Differences were considered significant when $p<0.05$.

\section{Results}

NMDA receptor antagonists dose-dependently increase the power and frequency of HFO in the mouse nucleus accumbens

Power spectra analysis of LFP recorded in the mouse NAc revealed the occurrence of weak spontaneous HFO (130$180 \mathrm{~Hz}$ ) in some, but not all mice. When present, spontaneous HFO were visible, typically as a small bump in the power spectra around $140 \mathrm{~Hz}$. LFP were recorded before and up to $1 \mathrm{~h}$ post-i.p. injection of ketamine $(10,25,50 \mathrm{mg} / \mathrm{kg}), \mathrm{MK} 801$ $(0.01,0.1,0.25,0.5 \mathrm{mg} / \mathrm{kg})$ or vehicle. Representative time courses expressed as spectrograms for each drug are shown in Fig. 1a, d. Repeated-measure ANOVA for HFO power revealed a significant group $\times$ time interaction $(F(222,888)=$ 12.68; $p<0.0001)$. Bonferroni post hoc analysis revealed HFO power significantly $(p<0.001)$ increased between 1 and $10 \mathrm{~min}$ post-injection of $25 \mathrm{mg} / \mathrm{kg}$ ketamine. The highest dose $(50 \mathrm{mg} / \mathrm{kg})$ produced a biphasic increase in HFO power, characterised by an immediate (phase 1) increase occurring in the first minute $(p<0.001)$, followed by a return to baseline power and a second increase (phase 2$)$ in power $(p<0.01)$ occurring 5 to $20 \mathrm{~min}$ post-injection. There were no significant differences in power between saline and the $10-\mathrm{mg} / \mathrm{kg}$ dose of ketamine. Consistent with our findings from rats, the power of HFO positively correlated with beam breaks (Supplementary Fig. 1). Repeated-measure ANOVA for HFO also revealed a group $\times$ time interaction $(F(222,888)=4.73 ; p<0.0001)$, with Bonferroni post hoc analysis revealing that $25 \mathrm{mg} / \mathrm{kg}$ ketamine increased HFO between 1 and $10 \mathrm{~min}(p<0.05)$, and $50 \mathrm{mg} / \mathrm{kg}$ ketamine associated with increases between 1 and 19 min post-injection $(p<0.001)$.

Systemic injection of MK801 also dose-dependently increased the power and frequency of HFO (Fig. 1e, f). Analyses of the time courses revealed significant group $\times$ time interactions for both HFO power and frequency $(F(308$, $1540) \leq 10.59 ; p<0.001)$. Increases in HFO power were found for 0.25 and $0.5 \mathrm{mg} / \mathrm{kg} \mathrm{MK} 801$, vs. saline, from 19 to $29 \mathrm{~min}$, respectively. Increases in frequency, with respect to saline, occurred from $19 \mathrm{~min}(0.1 \mathrm{mg} / \mathrm{kg})$ to $8 \mathrm{~min}(0.25$ and $0.5 \mathrm{mg} / \mathrm{kg})$.

\section{Clozapine dose-dependently reduces MK801-enhanced HFO in the mouse nucleus accumbens}

We next examined the effect of i.p. injection of the prototypical atypical antipsychotic compound, clozapine on HFO $30 \mathrm{~min}$ post-injection of $0.25 \mathrm{mg} / \mathrm{kg}$ MK801. Representative spectrograms showing the effect of clozapine or vehicle on HFO from the same mouse are shown in Fig. 2 (A1, A2). Clozapine dose-dependently reduced motor activation induced by injection of MK801 (one-way ANOVA, $F(3,5)=$ 
A

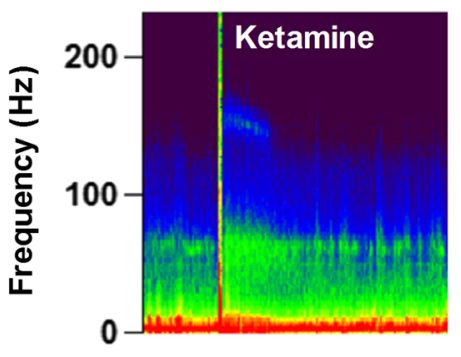

D

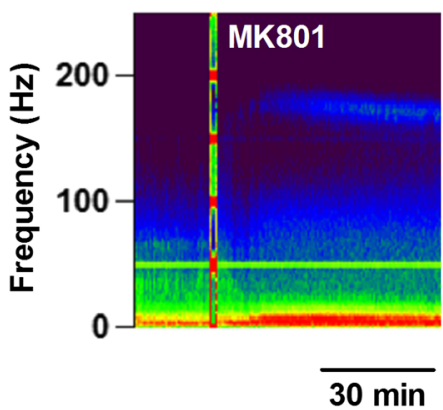

B

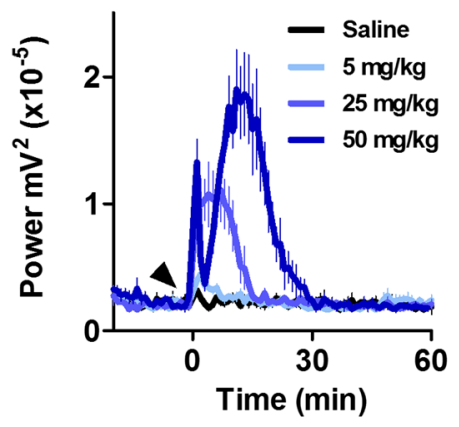

$E$

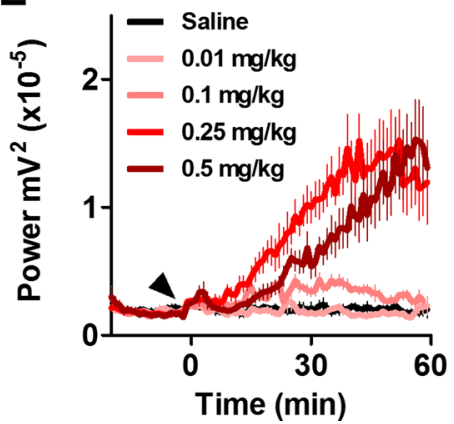

C

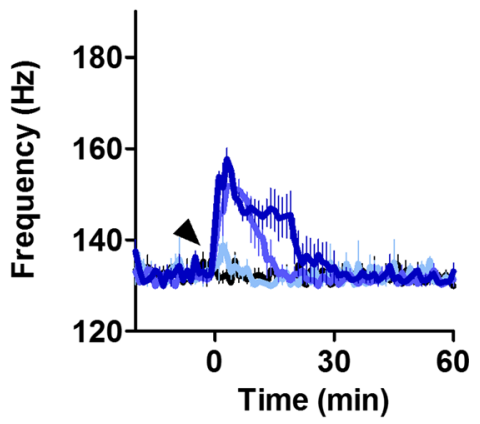

$\mathbf{F}$

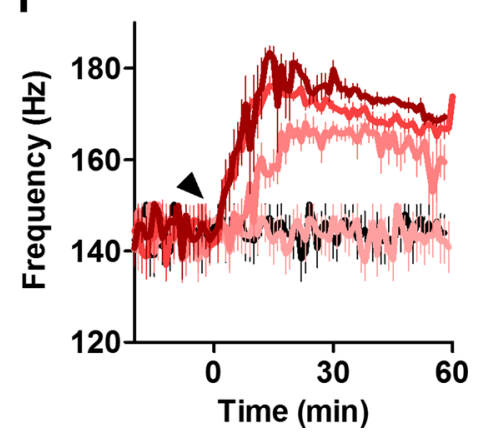

Fig. 1 NMDA receptor antagonists dose-dependently increase the power and frequency of HFO in the mouse NAc. a Accumbal LFP expressed as spectrograms showing the effect of intraperitoneal injection of $25 \mathrm{mg} / \mathrm{kg}$ ketamine. b, c Time courses showing the effect of different doses of ketamine $(5,25,50 \mathrm{mg} / \mathrm{kg}, N=4)$ on the power and frequency of HFO. d Accumbal LFP expressed as spectrograms showing the effect of intraperitoneal injection of $0.25 \mathrm{mg} / \mathrm{kg}$ MK801. e, $\mathbf{f}$ Time courses showing the effect of different doses of MK801 $(0.01,0.1,0.25,0.5 \mathrm{mg} / \mathrm{kg}, N=5)$ on the power and frequency of HFO. Saline was used as vehicle in both instances. Arrows indicate time of injection. Values are mean \pm SEM
A1
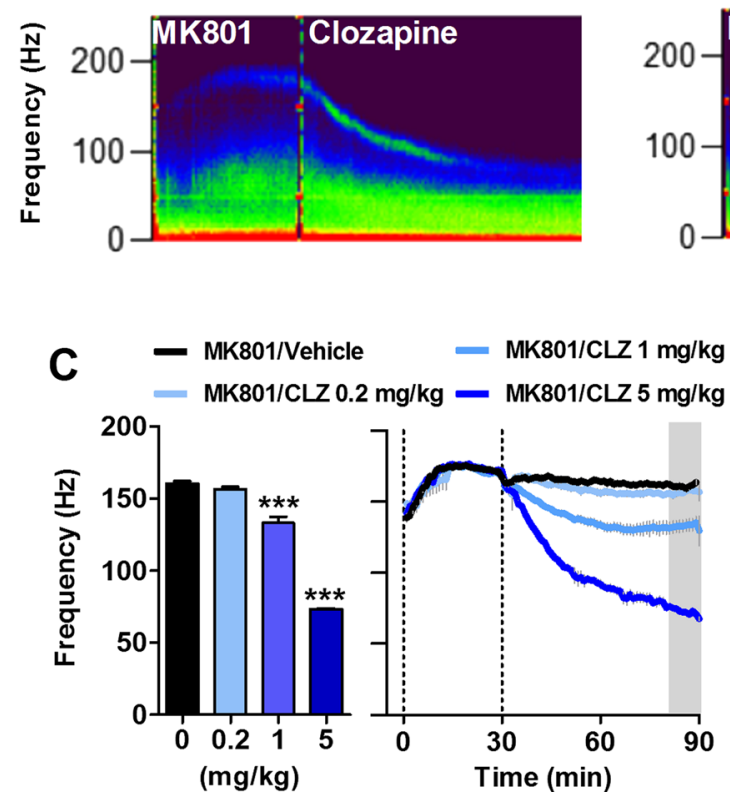

Fig. 2 The atypical antipsychotic clozapine dose-dependently decreases the frequency of HFO in the mouse NAc. A1, A2 Example spectrograms taken from the same mouse showing the effect of intraperitoneal injection of clozapine or vehicle on $0.25 \mathrm{mg} / \mathrm{kg}$ MK801-enhanced HFO. $B$ Total number of beam breaks after injection of clozapine. $C, D$ Histograms showing the effect of different doses of clozapine $(0.2,1,5 \mathrm{mg} / \mathrm{kg}, N=$
B
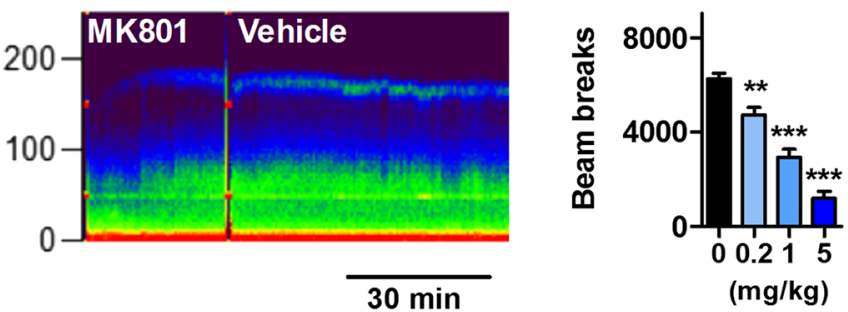

D

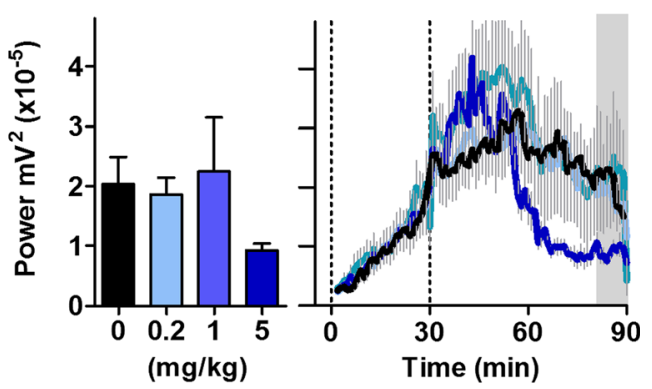

6) or vehicle on the frequency and power of MK801-enhanced HFO. Values are mean $\pm \mathrm{SEM}$ for a 10 -min period (approximately $50-60 \mathrm{~min}$ ) post-injection of clozapine and indicated by the shaded area shown on the time courses in the right-hand figure. ${ }^{* *} p<0.01$; ${ }^{* *} p<0.001 \mathrm{com}-$ pared with vehicle 
64.47; $p<0.0001$; Fig. 2b). Bonferroni post hoc analysis showed differences between vehicle and all doses of clozapine $(p<0.01)$. There were also differences between the lowest dose of clozapine and the medium and higher doses $(p<0.01)$ as well as between the medium and higher doses $(p<0.01)$

Clozapine $(0.2,1,5 \mathrm{mg} / \mathrm{kg})$ dose-dependently reduced the frequency of MK801-enhanced $\operatorname{HFO}(F(3,23)=250.6$; $p<0.0001$, repeated-measure one-way ANOVA; Fig. 2c). Bonferroni post hoc test revealed significant differences between vehicle vs. 1 and $5 \mathrm{mg} / \mathrm{kg}$ doses of clozapine $(p<0.001)$. Differences were also found between the lowest dose at $0.2 \mathrm{mg} / \mathrm{kg}$ and higher doses and between the 1- and 5$\mathrm{mg} / \mathrm{kg}$ doses $(p<0.001)$. We did not find a significant effect of clozapine on MK801-induced HFO power $(F(3,23)=1.6$; $p=0.23$, repeated-measure one-way ANOVA). Complete time courses are shown in Fig. 2d. Repeated-measure ANOVA of the time course revealed a significant group $\times$ time interaction $(F(243,1620)=54.1 ; p<0.0001)$. Bonferroni post hoc revealed the highest dose $(5 \mathrm{mg} / \mathrm{kg})$, produced a rapid effect on HFO with significant differences found from $5 \mathrm{~min}$ $(p<0.01)$ post-injection. The middle dose $(1 \mathrm{mg} / \mathrm{kg})$ produced significant reductions in frequency from $10 \mathrm{~min}$ post-injection $(p<0.01)$ with respect to vehicle. No differences were found between the lowest dose of clozapine and vehicle.

\section{Haloperidol does not influence the frequency of HFO in the mouse nucleus accumbens}

The effect of i.p. injection of the typical antipsychotic, haloperidol, on MK801-enhanced HFO is shown by a spectrogram in Fig. 3a. Injection of haloperidol $(1.5 \mathrm{mg} / \mathrm{kg})$ did not significantly affect the frequency (group $\times$ time, $F(83,1512)=0.69$; $p>0.05$; Fig. 3 b) or power $(t=0.172 ; d f=9 ; p=0.867$; Fig. $3 \mathrm{c})$. To test whether the administered dose had any effect on the animals, we also measured locomotor activity. Although this dose of haloperidol did not influence HFO power or frequency, it did reduce the amount of locomotor activation produced by MK801 ( $t=6.56 ; d f=3 ; p=0.0072$; Fig. $3 d$ ). We also examined the effect of a lower dose of haloperidol $(0.15 \mathrm{mg} / \mathrm{kg})$ in a separate group of mice. The time course is shown in Supplementary Fig. 2. The lower dose did not significantly influence the frequency (group $\times$ time, $F(85,680)=0.65$; $p>0.05)$ or power (group $\times$ time, $F(85,680)=0.59 ; p>0.05$ ) of MK801-enhanced HFO.

\section{Glycine and NMDA reduce MK801-enhanced HFO}

Glycine is a co-agonist of NMDA receptors which at high doses has been found to have antipsychotic properties in humans (Balu and Coyle 2015). We examined the effect of glycine at $2 \mathrm{~g} / \mathrm{kg}$ approximately $30 \mathrm{~min}$ after injection of MK801. Glycine produced a long-lasting reduction in the frequency of HFO. At $1 \mathrm{~h}$
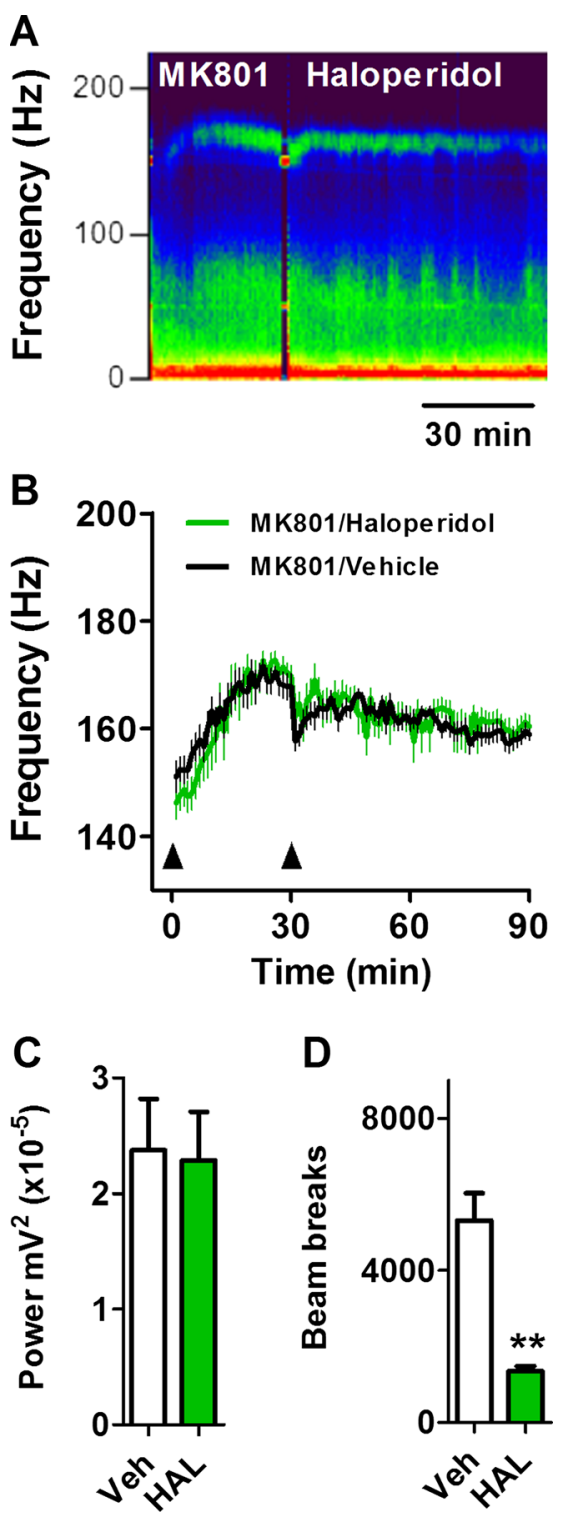

Fig. 3 The typical antipsychotic haloperidol does not reduce the frequency or power of HFO in the mouse NAc. a Example spectrogram from a representative mouse showing the effect of $1.5 \mathrm{mg} / \mathrm{kg}$ i.p. haloperidol on $0.25 \mathrm{mg} / \mathrm{kg}$ MK801-enhanced HFO. b Time courses showing the frequency of MK801-enhanced HFO before and after injection of haloperidol or vehicle $(N=10)$. Arrows indicate injection of MK801 and haloperidol, respectively. c Average power of MK801enhanced HFO after injection of haloperidol or vehicle. $\mathbf{d}$ Total number of beam breaks after injection of haloperidol was evaluated in four of the mice. Values are mean \pm SEM. $* * p<0.01$ compared with vehicle

post-treatment of glycine, the frequency of HFO was $133.3 \pm$ $7.9 \mathrm{~Hz}$ compared with $158.1 \pm 1.5 \mathrm{~Hz}$ for mice receiving saline ( $p=0.028$, paired $t$ test; Fig. $4 \mathrm{a}$ ). Analysis of the time course with repeated-measure ANOVA revealed a group $\times$ time interaction $(F(81,972)=6.99 ; p<0.0001)$. Significant reductions in HFO $(p<0.05)$ occurred from $15 \mathrm{~min}$ post-injection of glycine. Interestingly, the reduction in frequency appeared to occur in two phases, an initial rapid drop in frequency by approximately $15 \mathrm{~Hz}$, followed by a more gradual reduction in frequency over 

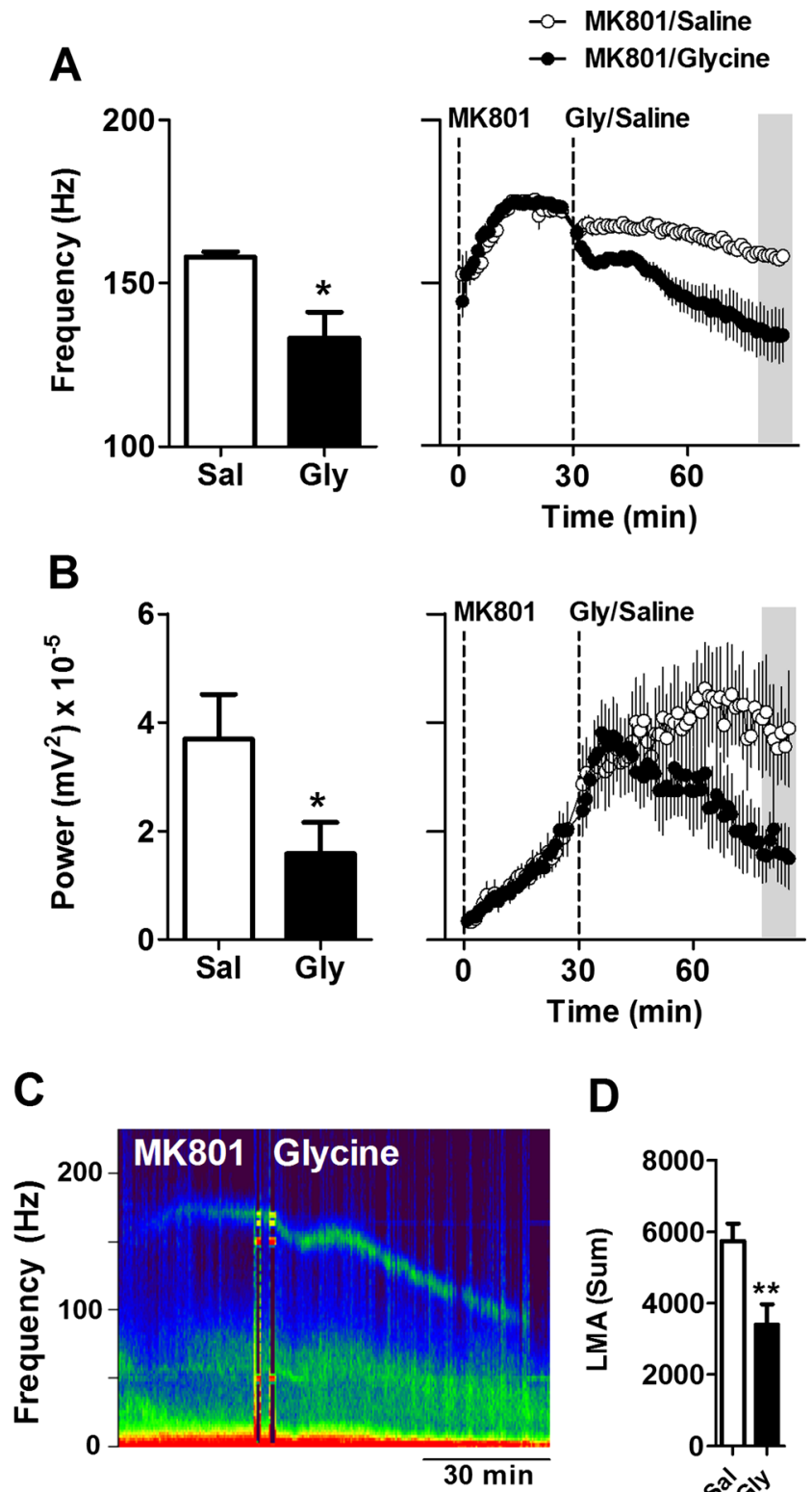

D

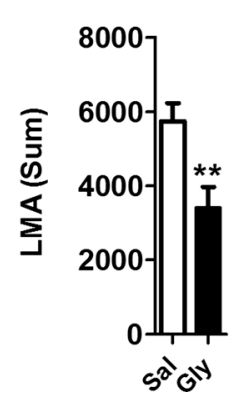

Fig. 4 Glycine reduces the frequency and power of MK801-enhanced HFO in mice. a, b Histograms showing the effect of $2 \mathrm{~g} / \mathrm{kg}$ glycine or saline on the frequency and power of MK801-enhanced HFO. Values are mean \pm SEM for a 10 -min period (approximately 50-60 min) postinjection of glycine and indicated by the shaded area shown on the time courses in the right-hand figure ( $N=7)$. $\mathbf{c}$ LFP expressed as a spectrogram from a representative mouse. d Total number of beam breaks postinjection of glycine or saline. Glycine reduces MK801-induced hyperlocomotion. ${ }^{*} p<0.05 ; * * p<0.01$ compared with vehicle

the course of the experiment. The power of HFO shows that $1 \mathrm{~h}$ post-glycine was also significantly lower compared with saline controls ( $p=0.0125$, paired $t$ test; Fig. $4 \mathrm{~b}$ ). A representative spectrogram showing the effect of glycine on MK801enhanced HFO is shown in Fig. 4c. Consistent with the findings of others (Nilsson et al. 1997), glycine also reduced MK801enhanced locomotion with respect to saline ( $p=0.026$, paired $t$ test; Fig. 4d).
Since glycine is known to potentiate NMDA receptor function, we next examined the effect of intraperitoneal injection of $75 \mathrm{mg} / \mathrm{kg}$ NMDA on the frequency of MK801-enhanced HFO. We found that NMDA produced an immediate and short-lasting reduction in frequency which typically lasted around $30 \mathrm{~min}$ but did not influence the power of HFO. Mean frequency at 10-20 min post-injection of $75 \mathrm{mg} / \mathrm{kg}$ NMDA was $149 \pm 3.2 \mathrm{~Hz}$ vs. $167.3 \pm 1.4 \mathrm{~Hz}$ from salineinjected mice ( $p=0.0014$, paired $t$ test; Fig. 5a). Analysis of the time course, using repeated-measure ANOVA, revealed a group $\times$ time interaction $(F(81,972)=9.63 ; p<0.0001)$. Significant reductions in HFO frequency $(p<0.01)$ occurred between 7 and 22 min post-injection of NMDA. Time courses are also shown in Fig. 5a, and a representative spectrogram is shown in Fig. 5b.

Stimulation of $5-\mathrm{HT}_{1 \mathrm{~A}}$ but not blockade of $5-\mathrm{HT}_{2 \mathrm{~A}}, 5-\mathrm{HT}_{7}$ or $\mathrm{H}_{3}$ receptors reduced the frequency of MK801-enhanced HFO

One-way ANOVA revealed a significant effect on the frequency of MK801-enhanced HFO $(F(4,29)=14.33 ; p<0.0001$; Fig. 6a). Bonferroni post hoc test revealed a significant reduction after injection of 8-OH-DPAT, a potent 5- $\mathrm{HT}_{1 \mathrm{~A}}$ agonist, compared with vehicle and the other drugs tested $(p<0.001)$. There were no significant changes in HFO frequency after systemic injection of antagonists at $5-\mathrm{HT}_{2 \mathrm{~A}}(1 \mathrm{mg} / \mathrm{kg}$ MDL11939) and 5-HT 7 receptors (1 mg/kg SB269970) or an $\mathrm{H}_{3}$ inverse agonist (5 mg/kg BF2649) with respect to control. No drug influenced the power of MK801-enhanced HFO $(F(4,29)=0.74 ; p=0.75$; Fig. $6 \mathrm{~b})$. Time course showing the effect of 8-OH-DPAT on the frequency of MK801-enhanced HFO is shown in Fig. 6c. Analysis of the time course, using repeated-measure ANOVA, revealed a group $\times$ time interaction $(F(85,850)=10.4 ; p<0.0001)$. Significant reductions in HFO $(p<0.01)$ occurred between 9 and 46 min post-injection of 8-OH-DPAT.

HFO are smaller amplitude but faster frequency in mice compared with rats

We carried out a further experiment to compare spontaneous and enhanced HFO in the BALB/c $(n=10)$ compared with the C57BL/6 strain. Due to the relatively small power of HFO at baseline, and the lack of a discernible peak in the spectra, it was not possible to consistently evaluate its frequency at baseline. We did, however, evaluate the integrated power for the HFO band (130-180 Hz) and found no significant difference for HFO power at baseline $(t=1.2 ; d f=35 ; p=0.23)$ or postinjection of $0.25 \mathrm{mg} / \mathrm{kg} \operatorname{MK} 801(t=1.5 ; d f=35 ; p=0.13)$. However, the frequency of MK801-enhanced HFO was significantly higher in C57BL/6 compared with BALB/c $(t=3.1$; $d f=35 ; p=0.0034)$. 


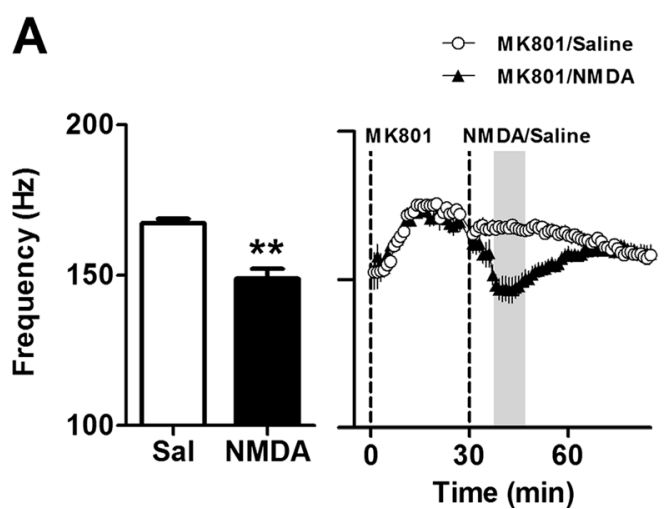

Fig. 5 NMDA reduces the frequency of MK801-enhanced HFO in mice. a Histogram showing the effect of $70 \mathrm{mg} / \mathrm{kg}$ NMDA or saline on the frequency of MK801-enhanced HFO $(N=7)$. Values are mean \pm SEM for a 10-min period approximately 10-20 min post-injection of NMDA and indicated by the shaded area shown on the time courses in the right-

We conducted further analyses to include data from our previously published rat studies to compare HFO in C57BL/ 6, BALB/c mice and Wistar rats. Analysis of integrated HFO power at baseline revealed significantly smaller $(p<0.01)$ power in both strains of mice compared with rats (one-way ANOVA, $F(2,66)=9.8 ; p<0.0002)$. The power between $\mathrm{BALB} / \mathrm{c}$ and $\mathrm{C} 57 \mathrm{BL} / 6$ was not significantly different.

We also examined the effect of MK801-enhanced HFO using data from our previously published rat studies at a dose of $0.15 \mathrm{mg} / \mathrm{kg}$. Although the dose of MK801 was lower in rats, analysis of the total HFO power 30 min post-injection revealed that the power of HFO was significantly higher in rats $(p<0.01)$ compared with both strains of mice, and no difference between the mouse strains (one-way ANOVA, $F(2,66)=29.9 ; p<0.0001)$. The frequency of MK801enhanced HFO was also significantly $(p<0.001)$ higher in mice $(\mathrm{C} 57 \mathrm{BL} / 6,170.1 \pm 1.2 \mathrm{~Hz}$; BALB/c, $163.2 \pm 1.3 \mathrm{~Hz})$ compared with rats (Wistar, $143.9 \pm 1.2 \mathrm{~Hz}$; one-way ANOVA, $F(2,64)=110.3 ; p<0.0001)$. We also found that
B

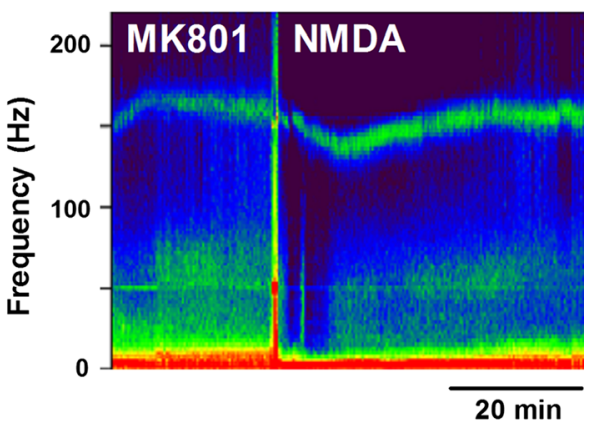

hand figure. This experiment was conducted using mice from the glycine study; therefore, control values shown are those from Fig. 4. b LFP expressed as a spectrogram from a representative mouse. ${ }^{* *} p<0.01 \mathrm{com}-$ pared with vehicle

the frequency of HFO post-MK801 was significantly higher in $\mathrm{C} 57 \mathrm{BL} / 6$ compared with BALB/c mice $(p<0.05)$.

Clozapine-induced reduction in HFO frequency was more substantial in C57BL/6 mice compared with Wistar rats $(p<0.001)$. In mice, clozapine $(5 \mathrm{mg} / \mathrm{kg})$ reduced the frequency by almost $100 \mathrm{~Hz}$, whilst in rats a higher dose of $15 \mathrm{mg} / \mathrm{kg}$ reduced HFO by around $50 \mathrm{~Hz}$. A dose of clozapine at $5 \mathrm{mg} / \mathrm{kg}$ in Wistar rats produced small effects on HFO (Olszewski et al. 2013b).

\section{Discussion}

NMDA receptor antagonists produced a sustained increase in the power and frequency of HFO in the mouse NAc. In the presence of MK801, the atypical antipsychotic drug, clozapine, dose-dependently reduced the frequency of HFO, whilst the typical antipsychotic drug, haloperidol, was without effect. Although we did observe some species differences between

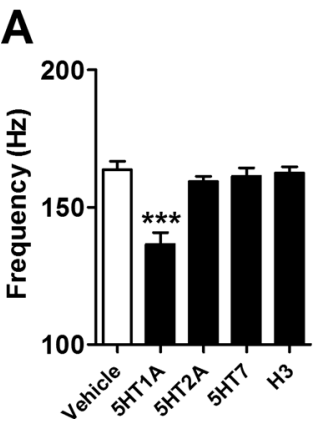

B

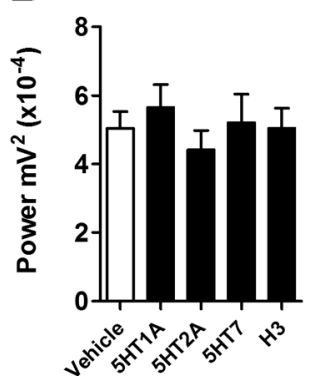

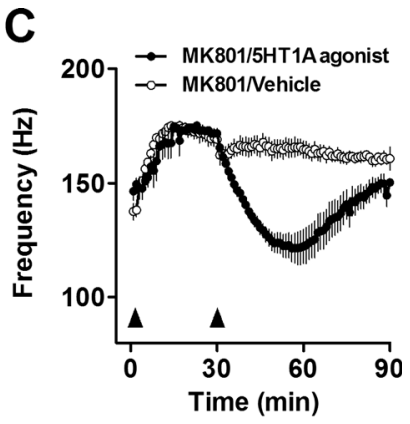

Fig. 6 Stimulation of 5-HT $\mathrm{T}_{1 \mathrm{~A}}$ receptors produces a short-lasting reduction in HFO. a, b Frequency and power of MK801-enhanced HFO (average $60 \mathrm{~min}$ ) post-injection of $1.0 \mathrm{mg} / \mathrm{kg} 8-\mathrm{OH}-\mathrm{DPAT}\left(5-\mathrm{HT}_{1 \mathrm{~A}}\right.$ agonist), $1.0 \mathrm{mg} / \mathrm{kg}$ MDL 11939 (5- $\mathrm{HT}_{2 \mathrm{~A}}$ antagonist), $1.0 \mathrm{mg} / \mathrm{kg} \mathrm{SB} 269970$ (5$\mathrm{HT}_{7}$ antagonist) and $5.0 \mathrm{mg} / \mathrm{kg} \mathrm{BF} 2649$ ( $\mathrm{H}_{3}$ inverse agonist). These compounds mimic some of the different pharmacological activities of clozapine at specific receptor targets $(N=5-6 /$ group $)$. Values are mean \pm SEM. c Time course showing the effect of intraperitoneal injection of the potent $5-\mathrm{HT}_{1 \mathrm{~A}}$ agonist 8-OH-DPAT on the frequency of MK801enhanced HFO. First arrow indicates injection of $0.25 \mathrm{mg} / \mathrm{kg}$ MK801; second arrow indicates injection of 8-OH-DPAT or vehicle. $* * * p<0.001$ 
mice and rats, the findings reported here are broadly in line with our previous studies using rats (Hunt et al. 2006; Olszewski et al. 2013b).

\section{Clozapine and glycine reduce HFO frequency}

Clozapine dose-dependently reduced the frequency of HFO in mice; at the highest dose, an approximate $80 \mathrm{~Hz}$ reduction was observed. Effects of clozapine were examined against a background of MK801-enhanced HFO. The dose of MK801 we used is similar to earlier studies where behavioural effects of antipsychotic compounds have been evaluated (Ninan and Kulkarni 1998; Bradford et al. 2010). As expected, clozapine dose-dependently reduced MK801-induced locomotor activity. Haloperidol, at a dose that produced an equivalent reduction in locomotor activity, did not influence the frequency of power of HFO, in line with our findings in rats (Olszewski et al. 2013b). A low dose of haloperidol $(0.15 \mathrm{mg} / \mathrm{kg})$, close to the concentration reported to reverse effect of phencyclidineinduced increase in cortical pyramidal cell firing (Kargieman et al. 2007), was also without effect on the increases in HFO power or frequency produced by MK801. These findings corroborate our earlier study in rats which indicate that reduction in HFO may be an electrophysiological signature of 'atypicality'. Since the baseline power of HFO, in mice, was often negligible, we could not adequately determine the effect of clozapine on baseline activity. However, in our previous study, using rats - which typically display a clear peak in the HFO range, we observed clozapine, but not haloperidol, reduced the frequency of HFO, indicating that atypical drugs differentially interact with the fundamental mechanisms responsible for the generation of HFO in the NAc.

Enhancing NMDA receptor neurotransmission at the glycine modulatory site has been proposed as an effective therapeutic strategy for the treatment of schizophrenia (Balu and Coyle 2015). There is good evidence from pre-clinical studies that demonstrates glycine and compounds which enhance synaptic glycine levels possess antipsychotic efficacy. In animal models, these compounds reduce psychotomimetic-induced hyperlocomotion (Boulay et al. 2008), as well as cognitive deficits induced by NMDA receptor antagonists, including attentional deficits, novel object recognition and latent inhibition (Depoortere et al. 2005; Karasawa et al. 2008; Black et al. 2009). Glycine has been shown to reverse deficits in pre-pulse inhibition in a rat neonatal ventral hippocampal lesion model (Le Pen et al. 2003). In this study, we found that glycine also produced a robust reduction in the frequency of HFO. This is potentially interesting since it corroborates our previous finding that drugs with antipsychotic properties, particularly those effective in controlling the negative and cognitive symptoms of schizophrenia, reduce the frequency of HFO in the NAc (Olszewski et al. 2013b).

\section{Modulation of accumbal HFO by NMDA and 5-HT $1 \mathrm{~A}$ receptors}

Potentiation of NMDA receptor function either directly (injection of NMDA) or indirectly (glycine) reduced the frequency of HFO. NMDA receptors play an important role in the activity of medium spiny neurons, in particular the transition from hyperpolarised 'down' states to 'up' ready-to-fire states (Vergara et al. 2003; Wolf et al. 2005). Both clozapine and risperidone potentiate NMDA receptor neurotransmission in cortical neurons (Konradsson et al. 2006). Additionally, using whole patch cell recordings, it has been shown that bath application of clozapine, but not haloperidol or the $5-\mathrm{HT}_{2 \mathrm{~A}}$ antagonist MDL100907, potentiates NMDA receptor currents in NAc neurons (Wittmann et al. 2005). Notably, sulpiride, which we showed previously can reduce HFO in rats, also significantly increased NMDA receptor currents in NAc neurons (Wittmann et al. 2005). These findings point to a pivotal role played by NMDA receptors in influencing the frequency of HFO recorded in the NAc. However, other receptor systems can also influence the frequency of HFO. We found that 8-OHDPAT, an agonist at 5- $\mathrm{HT}_{1 \mathrm{~A}}$ receptors, reduced the frequency of NMDA receptor antagonist-enhanced HFO. Clozapine and several other atypical antipsychotic drugs possess partial agonistic activity at 5- $\mathrm{HT}_{1 \mathrm{~A}}$ receptors (for review, see Celada et al. 2013). Compounds which possess combined $5-\mathrm{HT}_{2 \mathrm{~A}} / \mathrm{D}_{2}$ properties with direct $5-\mathrm{HT}_{1 \mathrm{~A}}$ receptor agonistic properties are active in a broad range of models of schizophrenia. These observations have led to the development of novel antipsychotic compounds such as aripiprazole and lurasidone (for review, see Newman-Tancredi and Kleven 2011). The present study shows that NMDA and $5-\mathrm{HT}_{1 \mathrm{~A}}$ receptors can influence the frequency of accumbal HFO, whilst it may be inferred we have not categorically demonstrated that clozapine exerts its effects on HFO through either of these receptors. Clozapine possesses antagonist properties at many other receptors, including 5$\mathrm{HT}_{2 \mathrm{~A}}$ (Canton et al. 1994), 5-HT 7 (Roth et al. 1994) and $\mathrm{H}_{3}$ receptors (Rodrigues et al. 1995). Blockade of these receptors did not influence the frequency of MK801-enhanced HFO, indicating that clozapine and other antipsychotic compounds do not exert their effects on HFO through these receptors.

NMDA receptor antagonists appear to preferentially block NMDA receptors in cortical interneurons (Homayoun and Moghaddam 2007) and GABAergic neurons of the reticular nucleus of the thalamus (Troyano-Rodriguez et al. 2014). Although the major cell type in the NAc is medium spiny projection neurons, which comprise between 90 and $95 \%$, several different classes of interneurons are known to be present, including calbindin, parvalbumin, somatostatin and large cholinergic subtypes (Berke 2011; Russo and Nestler 2013). Whether NMDA receptor antagonists preferentially target specific neuronal subtypes warrants investigation, possibly using optogenetic techniques. As well as local mechanisms, 
afferent projections are likely to play a role in the generation of HFO. Indeed, we have shown previously that local injection of clozapine to the NAc of rats does not mimic the effects observed after systemic injection (Olszewski et al. 2013b). The NAc receives glutamatergic projections from the prefrontal cortex, amygdala, hippocampus and thalamus (Groenewegen et al. 1999), and a dense dopaminergic projection from the ventral tegmental area. Although NMDA receptor antagonists can increase the firing of prefrontal cortical neurons (Homayoun and Moghaddam 2007), infusion of TTX to the prelimbic region of the prefrontal cortex did not disrupt MK801-enhanced HFO in rats (Olszewski et al. 2013a), suggesting that this region does not drive HFO in the NAc.

\section{Accumbal HFO in mice and rats}

In mice, spontaneous HFO were rarely observed, and when present, they could only be detected as a very small bump in the averaged power spectra. This is quite different in rats where spontaneous HFO are clearly visible in the majority of recordings from the NAc. Given the smaller power at baseline in mice, it is not surprising that HFO power postNMDA receptor antagonist injection was also smaller. However, the fundamental effects produced by NMDA receptor antagonists on mechanisms generating HFO appear to be similar in mice and rats. For example, the temporal changes seen in HFO power generated after NMDA receptor antagonists closely follow those previously reported in rats (Hunt et al. 2006; Nicolas et al. 2011). In both mice and rats, ketamine produced a rapid short-lasting increase in power, whilst MK801 generated HFO which persisted throughout the course of the experiments. Changes in locomotion and HFO power positively correlated a finding consistent with our previous study (Hunt et al. 2006).

With respect to HFO, the frequency of post-injection of MK801 was $170.1 \pm 1.2 \mathrm{~Hz}$ compared with $146.3 \pm 1.2 \mathrm{~Hz}$ in rats. Mice strains vary substantially in their behavioural response to NMDA receptor antagonists and antipsychotic drugs. Therefore, we also examined HFO in the behaviourally distinct BALB/c strain of mice (Holmes et al. 2002; Sik et al. 2003; Bothe et al. 2005). Like C57BL/6 mice, HFO in the $\mathrm{BALB} / \mathrm{c}$ strain was lower in power but higher in frequency compared with Wistar rats. Although HFO power was not different between the two mice strains, we found that the frequency of HFO was slightly lower in BALB/c mice.

When we examined the effects produced by clozapine, there were certain notable differences between our mice and previously published rat study. Firstly, the dose of clozapine efficacious at reducing HFO was lower in mice than rats; a dose of $5 \mathrm{mg} / \mathrm{kg}$ robustly reduced the frequency, by around $80 \mathrm{~Hz}$, in mice, whilst in rats, the same dose produced only weak $10-20 \mathrm{~Hz}$ reductions. Additionally, at this dose in mice after a subtle increase in power, we observed a dramatic reduction in power which typically occurred when HFO reached approximately $100 \mathrm{~Hz}$. In rats, clozapine potentiated the power of HFO whilst simultaneously reducing HFO. One possible explanation for this difference is methodology. In our previous rat study, the dose of MK801 used was submaximal (Olszewski et al. 2013b). In the current study, using mice, we used a dose of MK801 that produced close to maximal increases in HFO power; therefore, further potentiation of HFO power may not be physiologically possible. Notwithstanding, although there are certain characteristic differences between the species, the fundamental effects produced by NMDA receptor antagonists and antipsychotics on HFO appear broadly similar in mice and rats.

\section{Conclusions}

These findings show that although HFO power and frequency are different in rats and mice, the effects produced by psychotomimetic and antipsychotic compounds are broadly similar in both species. These data also suggest that atypical antipsychotic drugs may reduce the frequency of HFO by interacting with NMDA and/or 5- $\mathrm{HT}_{1 \mathrm{~A}}$ receptors.

Acknowledgements This work was financed by the National Science Centre (Poland) grant NCS DEC-2011/03/B/NZ4/03053 and the Wellcome Trust (UK).

Open Access This article is distributed under the terms of the Creative Commons Attribution 4.0 International License (http:// creativecommons.org/licenses/by/4.0/), which permits unrestricted use, distribution, and reproduction in any medium, provided you give appropriate credit to the original author(s) and the source, provide a link to the Creative Commons license, and indicate if changes were made.

\section{References}

Balu DT, Coyle JT (2015) The NMDA receptor 'glycine modulatory site' in schizophrenia: d-serine, glycine, and beyond. Curr Opin Pharmacol 20C:109-115

Berke JD (2011) Functional properties of striatal fast-spiking interneurons. Front Syst Neurosci 5:45

Black MD, Varty GB, Arad M, Barak S, De Levie A, Boulay D, Pichat P, Griebel G, Weiner I (2009) Procognitive and antipsychotic efficacy of glycine transport 1 inhibitors (GlyT1) in acute and neurodevelopmental models of schizophrenia: latent inhibition studies in the rat. Psychopharmacology 202:385-396

Bothe GW, Bolivar VJ, Vedder MJ, Geistfeld JG (2005) Behavioral differences among fourteen inbred mouse strains commonly used as disease models. Comp Med 55:326-334

Boulay D, Pichat P, Dargazanli G, Estenne-Bouhtou G, Terranova JP, Rogacki N, Stemmelin J, Coste A, Lanneau C, Desvignes C, Cohen C, Alonso R, Vige X, Biton B, Steinberg R, Sevrin M, Oury-Donat F, George P, Bergis O, Griebel G, Avenet P, Scatton B (2008) Characterization of SSR103800, a selective inhibitor of the 
glycine transporter-1 in models predictive of therapeutic activity in schizophrenia. Pharmacol Biochem Behav 91:47-58

Brabant C, Charlier Y, Tirelli E (2013) The histamine H(3)-receptor inverse agonist pitolisant improves fear memory in mice. Behav Brain Res 243:199-204

Bradford AM, Savage KM, Jones DN, Kalinichev M (2010) Validation and pharmacological characterisation of MK-801-induced locomotor hyperactivity in $\mathrm{BALB} / \mathrm{C}$ mice as an assay for detection of novel antipsychotics. Psychopharmacology 212:155-170

Canton H, Verriele L, Millan MJ (1994) Competitive antagonism of serotonin (5-HT)2C and 5-HT2A receptor-mediated phosphoinositide (PI) turnover by clozapine in the rat: a comparison to other antipsychotics. Neurosci Lett 181:65-68

Ceglia I, Carli M, Baviera M, Renoldi G, Calcagno E, Invernizzi RW (2004) The 5-HT receptor antagonist M100,907 prevents extracellular glutamate rising in response to NMDA receptor blockade in the mPFC. J Neurochem 91:189-199

Celada P, Bortolozzi A, Artigas F (2013) Serotonin 5-HT1A receptors as targets for agents to treat psychiatric disorders: rationale and current status of research. CNS Drugs 27:703-716

Depoortere R, Dargazanli G, Estenne-Bouhtou G, Coste A, Lanneau C, Desvignes C, Poncelet M, Heaulme M, Santucci V, Decobert M, Cudennec A, Voltz C, Boulay D, Terranova JP, Stemmelin J, Roger P, Marabout B, Sevrin M, Vige X, Biton B, Steinberg R, Francon D, Alonso R, Avenet P, Oury-Donat F, Perrault G, Griebel G, George P, Soubrie P, Scatton B (2005) Neurochemical, electrophysiological and pharmacological profiles of the selective inhibitor of the glycine transporter-1 SSR504734, a potential new type of antipsychotic. Neuropsychopharmacol: Off Publ Am Coll Neuropsychopharmacol 30:1963-1985

Gleason SD, Shannon HE (1997) Blockade of phencyclidine-induced hyperlocomotion by olanzapine, clozapine and serotonin receptor subtype selective antagonists in mice. Psychopharmacology 129: $79-84$

Grace AA (2000) Gating of information flow within the limbic system and the pathophysiology of schizophrenia. Brain Res Brain Res Rev $31: 330-341$

Groenewegen HJ, Wright CI, Beijer AV, Voorn P (1999) Convergence and segregation of ventral striatal inputs and outputs. Ann N Y Acad Sci 877:49-63

Higgins GA, Enderlin M, Haman M, Fletcher PJ (2003) The 5-HT2A receptor antagonist M100,907 attenuates motor and impulsivetype' behaviours produced by NMDA receptor antagonism. Psychopharmacology 170:309-319

Hiyoshi T, Kambe D, Karasawa J, Chaki S (2014) Differential effects of NMDA receptor antagonists at lower and higher doses on basal gamma band oscillation power in rat cortical electroencephalograms. Neuropharmacology 85:384-396

Holmes A, Wrenn CC, Harris AP, Thayer KE, Crawley JN (2002) Behavioral profiles of inbred strains on novel olfactory, spatial and emotional tests for reference memory in mice. Genes Brain Behav 1: 55-69

Homayoun H, Moghaddam B (2007) NMDA receptor hypofunction produces opposite effects on prefrontal cortex interneurons and pyramidal neurons. J Neurosci: Off J Soc Neurosci 27:11496-11500

Horiguchi M, Huang M, Meltzer HY (2011) The role of 5hydroxytryptamine 7 receptors in the phencyclidine-induced novel object recognition deficit in rats. J Pharmacol Exp Ther 338:605614

Hunt MJ, Falinska M, Kasicki S (2010) Local injection of MK801 modifies oscillatory activity in the nucleus accumbens in awake rats. $\mathrm{J}$ Psychopharmacol 24:931-941

Hunt MJ, Falinska M, Leski S, Wojcik DK, Kasicki S (2011) Differential effects produced by ketamine on oscillatory activity recorded in the rat hippocampus, dorsal striatum and nucleus accumbens. J Psychopharmacol 25:808-821
Hunt MJ, Raynaud B, Garcia R (2006) Ketamine dose-dependently induces high-frequency oscillations in the nucleus accumbens in freely moving rats. Biol Psychiatry 60:1206-1214

Ito C (2009) Histamine H3-receptor inverse agonists as novel antipsychotics. Cent Nerv Syst Agents Med Chem 9:132-136

Ji B, Wang X, Pinto-Duarte A, Kim M, Caldwell S, Young JW, Behrens MM, Sejnowski TJ, Geyer MA, Zhou X (2013) Prolonged ketamine effects in hypomorphic mice: mimicking phenotypes of schizophrenia. PLoS ONE 8:e66327

Karasawa J, Hashimoto K, Chaki S (2008) D-Serine and a glycine transporter inhibitor improve MK-801-induced cognitive deficits in a novel object recognition test in rats. Behav Brain Res 186:78-83

Kargieman L, Santana N, Mengod G, Celada P, Artigas F (2007) Antipsychotic drugs reverse the disruption in prefrontal cortex function produced by NMDA receptor blockade with phencyclidine. Proc Natl Acad Sci U S A 104:14843-14848

Kocsis B (2012) Differential role of NR2A and NR2B subunits in $\mathrm{N}$ methyl-D-aspartate receptor antagonist-induced aberrant cortical gamma oscillations. Biol Psychiatry 71:987-995

Konradsson A, Marcus MM, Hertel P, Svensson TH, Jardemark KE (2006) Inhibition of the glycine transporter GlyT-1 potentiates the effect of risperidone, but not clozapine, on glutamatergic transmission in the rat medial prefrontal cortex. Synapse 60:102-108

Krystal JH, Karper LP, Seibyl JP, Freeman GK, Delaney R, Bremner JD, Heninger GR, Bowers MB Jr, Charney DS (1994) Subanesthetic effects of the noncompetitive NMDA antagonist, ketamine, in humans. Psychotomimetic, perceptual, cognitive, and neuroendocrine responses. Arch Gen Psychiatry 51:199-214

Kulikova SP, Tolmacheva EA, Anderson P, Gaudias J, Adams BE, Zheng T, Pinault D (2012) Opposite effects of ketamine and deep brain stimulation on rat thalamocortical information processing. Eur J Neurosci 36:3407-3419

Lahti AC, Koffel B, LaPorte D, Tamminga CA (1995) Subanesthetic doses of ketamine stimulate psychosis in schizophrenia. Neuropsychopharmacol: Off Publ Am Coll Neuropsychopharmacol 13:9-19

Lazarewicz MT, Ehrlichman RS, Maxwell CR, Gandal MJ, Finkel LH, Siegel SJ (2010) Ketamine modulates theta and gamma oscillations. J Cogn Neurosci 22:1452-1464

Le Pen G, Kew J, Alberati D, Borroni E, Heitz MP, Moreau JL (2003) Prepulse inhibition deficits of the startle reflex in neonatal ventral hippocampal-lesioned rats: reversal by glycine and a glycine transporter inhibitor. Biol Psychiatry 54:1162-1170

Ligneau X, Landais L, Perrin D, Piriou J, Uguen M, Denis E, Robert P, Parmentier R, Anaclet C, Lin JS, Burban A, Arrang JM, Schwartz JC (2007) Brain histamine and schizophrenia: potential therapeutic applications of H3-receptor inverse agonists studied with BF2.649. Biochem Pharmacol 73:1215-1224

Ma J, Leung LS (2000) Relation between hippocampal gamma waves and behavioral disturbances induced by phencyclidine and methamphetamine. Behav Brain Res 111:1-11

McOmish CE, Lira A, Hanks JB, Gingrich JA (2012) Clozapine-induced locomotor suppression is mediated by 5 -HT2A receptors in the forebrain. Neuropsychopharmacol: Off Publ Am Coll Neuropsychopharmacol 37:2747-2755

Meltzer HY (1999) The role of serotonin in antipsychotic drug action. Neuropsychopharmacol: Off Publ Am Coll Neuropsychopharmacol 21:106S-115S

Middleton S, Jalics J, Kispersky T, Lebeau FE, Roopun AK, Kopell NJ, Whittington MA, Cunningham MO (2008) NMDA receptordependent switching between different gamma rhythm-generating microcircuits in entorhinal cortex. Proc Natl Acad Sci U S A 105: 18572-18577

Mirjana C, Baviera M, Invernizzi RW, Balducci C (2004) The serotonin 5-HT2A receptors antagonist M100907 prevents impairment in attentional performance by NMDA receptor blockade in the rat 
prefrontal cortex. Neuropsychopharmacol: Off Publ Am Coll Neuropsychopharmacol 29:1637-1647

Newman-Tancredi A, Kleven MS (2011) Comparative pharmacology of antipsychotics possessing combined dopamine D2 and serotonin 5HT1A receptor properties. Psychopharmacology 216:451-473

Nicolas MJ, Lopez-Azcarate J, Valencia M, Alegre M, Perez-Alcazar M, Iriarte J, Artieda J (2011) Ketamine-induced oscillations in the motor circuit of the rat basal ganglia. PLoS ONE 6:e21814

Nikiforuk A, Kos T, Fijal K, Holuj M, Rafa D, Popik P (2013) Effects of the selective 5-HT7 receptor antagonist SB-269970 and amisulpride on ketamine-induced schizophrenia-like deficits in rats. PLoS ONE 8:e66695

Nilsson M, Carlsson A, Carlsson ML (1997) Glycine and D-serine decrease MK-801-induced hyperactivity in mice. J Neural Transm 104:1195-1205

Ninan I, Kulkarni SK (1998) 5-HT2A receptor antagonists block MK801-induced stereotypy and hyperlocomotion. Eur J Pharmacol 358: $111-116$

Olszewski M, Dolowa W, Matulewicz P, Kasicki S, Hunt MJ (2013a) NMDA receptor antagonist-enhanced high frequency oscillations: are they generated broadly or regionally specific? Eur Neuropsychopharmacol: J Eur Coll Neuropsychopharmacol 23: 1795-1805

Olszewski M, Piasecka J, Goda SA, Kasicki S, Hunt MJ (2013b) Antipsychotic compounds differentially modulate highfrequency oscillations in the rat nucleus accumbens: a comparison of first- and second-generation drugs. Int $J$ Neuropsychopharmacol/Off Sci J Coll Int Neuropsychopharmacol 16:1009-1020

Phillips KG, Cotel MC, McCarthy AP, Edgar DM, Tricklebank M, O'Neill MJ, Jones MW, Wafford KA (2012) Differential effects of NMDA antagonists on high frequency and gamma EEG oscillations in a neurodevelopmental model of schizophrenia. Neuropharmacology 62:1359-1370

Pinault D (2008) N-methyl d-aspartate receptor antagonists ketamine and MK-801 induce wake-related aberrant gamma oscillations in the rat neocortex. Biol Psychiatry 63:730-735
Rodrigues AA, Jansen FP, Leurs R, Timmerman H, Prell GD (1995) Interaction of clozapine with the histamine $\mathrm{H} 3$ receptor in rat brain. Br J Pharmacol 114:1523-1524

Roopun AK, Cunningham MO, Racca C, Alter K, Traub RD, Whittington MA (2008) Region-specific changes in gamma and beta2 rhythms in NMDA receptor dysfunction models of schizophrenia. Schizophr Bull 34:962-973

Roth BL, Craigo SC, Choudhary MS, Uluer A, Monsma FJ Jr, Shen Y, Meltzer HY, Sibley DR (1994) Binding of typical and atypical antipsychotic agents to 5-hydroxytryptamine-6 and 5hydroxytryptamine-7 receptors. J Pharmacol Exp Ther 268: $1403-1410$

Russo SJ, Nestler EJ (2013) The brain reward circuitry in mood disorders. Nat Rev Neurosci 14:609-625

Sik A, van Nieuwehuyzen P, Prickaerts J, Blokland A (2003) Performance of different mouse strains in an object recognition task. Behav Brain Res 147:49-54

Spencer KM (2011) Baseline gamma power during auditory steady-state stimulation in schizophrenia. Front Hum Neurosci 5:190

Troyano-Rodriguez E, Llado-Pelfort L, Santana N, Teruel-Marti V, Celada P, Artigas F (2014) Phencyclidine inhibits the activity of thalamic reticular gamma-aminobutyric acidergic neurons in rat brain. Biol Psychiatry 76:937-945

Uhlhaas PJ, Singer W (2010) Abnormal neural oscillations and synchrony in schizophrenia. Nat Rev Neurosci 11:100-113

Vergara R, Rick C, Hernandez-Lopez S, Laville JA, Guzman JN, Galarraga E, Surmeier DJ, Bargas J (2003) Spontaneous voltage oscillations in striatal projection neurons in a rat corticostriatal slice. J Physiol 553:169-182

Wittmann M, Marino MJ, Henze DA, Seabrook GR, Conn PJ (2005) Clozapine potentiation of $N$-methyl-D-aspartate receptor currents in the nucleus accumbens: role of NR2B and protein kinase $\mathrm{A} / \mathrm{Src}$ kinases. J Pharmacol Exp Ther 313:594-603

Wolf JA, Moyer JT, Lazarewicz MT, Contreras D, Benoit-Marand M, O'Donnell P, Finkel LH (2005) NMDA/AMPA ratio impacts state transitions and entrainment to oscillations in a computational model of the nucleus accumbens medium spiny projection neuron. $\mathrm{J}$ Neurosci: Off J Soc Neurosci 25:9080-9095 